Przegląd Narodowościowy / Review of Nationalities • nr 7/2017 • World of Slavs / Świat Słowian

\title{
The ideas, objectives and instruments of the Eastern policy in the Second Republic
}

\author{
Idee, cele i instrumenty polityki wschodniej \\ w II Rzeczypospolitej
}

The Eastern lands of the Second Republic were, as widely known, the area where most of the residents were citizens who belong to a other nationalities than Polish. Only on the areas situated north of latitudinal course of the upper Neman River and in Eastern Galicia Polish population density was higher, mainly on Wileńszczyzna (the Vilnius Region) where they exceed $50 \%$ of the total population. Therefore, the question of national minorities constituted a serious internal problem of the state, because they counted in total, throughout Poland, in fact more than 30\% of the population. Moreover, they often showed their hostile attitude towards the Polish state, which mainly concerned the Ukrainian population. This state of affairs lay the basis for the government circles to take efforts towards deeper processing relationships in the eastern borderlands, in order to fully integrate the area with the rest of the country. These actions were supported, inter alia, by various types of research providing the authorities with reliable information needed to conduct appropriate policy (from the point of view
Ziemie Wschodnie II Rzeczypospolitej były, jak wiadomo, obszarem, gdzie większość mieszkańców stanowili obywatele należący do innych narodowości niż polska. Jedynie na terenach znajdujących się na północ od równoleżnikowego biegu górnego Niemna oraz w Małopolsce Wschodniej zagęszczenie ludności polskiej było większe, przede wszystkim na Wileńszczyźnie, gdzie przekraczało 50\% ogółu mieszkańców. W związku z tym kwestia mniejszościowa stanowiła poważny problem wewnętrzny państwa, mniejszości narodowe liczone łącznie, na całym terytorium Polski, wynosiły bowiem ponad 30\% mieszkańców kraju, co więcej niejednokrotnie wykazywały swoją wrogą postawę w stosunku do państwa polskiego, co przede wszystkim dotyczyło ludności ukraińskiej. Powyższy stan rzeczy legł u podstaw podjęcia przez sfery rządzące wysiłków w kierunku głębszego przetworzenia stosunków na kresach wschodnich, celem całkowitego zintegrowania tego terenu z resztą kraju. Działaniom tym miały służyć m.in. różnego rodzaju badania naukowe dostarczające władzom miaro-

* Correspondence address: Instytut Religioznawstwa, Uniwersytet Jagielloński, ul. Grodzka 52, 31-044 Kraków, Polska, e-mail: letocharaf@poczta.onet.pl. 
of the state) towards the Eastern Territories. Those expert opinions, although, as declared their authors, were carried out carefully by independent researchers, were however organically linked with the policy of the authorities towards national minorities, as they were meant to provide the expected amount of information needed to carry out specific policy. Goals that serve It was mentioned in the title centers which were Instytut Badań Spraw Narodowościowych (Institute for Research Nationality Affairs - IBSN) and Komisja Naukowych Badań Ziem Wschodnich (the Commission for Scientific Research of Eastern Territories - KNBZW). The first one was established in 1921, when the problem of minorities was already obvious in the rebuilt country. However, during the period till the May Coup the Institute did not develop a broader activity. Its bloom did not take place until 1926. KNBZW was appointed for life in 1934. In addition to these two centers there were also other institutions in the country of a similar nature and similar tasks, such as Instytut Wschodni (the Eastern Institute) in Warsaw, Instytut Naukowo-Badawczy Europy Wschodniej (the Scientific-Research Institute of Eastern Europe) in Vilnius and Towarzystwo Rozwoju Ziem Wschodnich (the Society for the Development of the Eastern Lands), but they were not described in detail in Olgierd Grott's work. The author confined himself in his book to actions of IBSN and KNBZW and to characterize their work. They, as he rightly observed, played a major role in examin- dajnych informacji potrzebnych do prowadzenia odpowiedniej z punktu widzenia interesów państwa polityki w stosunku do Ziem Wschodnich. Ekspertyzy te choć same w sobie, jak deklarowali ich autorzy, przeprowadzane były w warunkach należytej niezależności badaczy, zostały jednak powiązane organicznie z polityką władz wobec mniejszości narodowych, gdyż miały z założenia dostarczać oczekiwanej sumy informacji potrzebnych do prowadzenia określonej polityki. Celom tym służyły właśnie wymienione w tytule ośrodki, jakimi były Instytut Badań Spraw Narodowościowych (IBSN) oraz Komisja Naukowych Badań Ziem Wschodnich (KNBZW). Pierwsza $\mathrm{z}$ nich powstała w 1921 r., kiedy problem mniejszości był już oczywistością w odbudowanym państwie. Niemniej jednak w okresie do przewrotu majowego Instytut nie rozwinął szerszej działalności, o jego rozkwicie możemy mówić dopiero po $1926 \mathrm{r}$. W $1934 \mathrm{r}$. zaś powołany zostaje do życia KNBZW. Oprócz tych dwóch ośrodków istniały także i inne instytucje w kraju o zbliżonym charakterze i podobnych zadaniach, jak np. Instytut Wschodni w Warszawie, Instytut Naukowo-Badawczy Europy Wschodniej w Wilnie oraz Towarzystwo Rozwoju Ziem Wschodnich, niemniej jednak nie zostały one w pracy Olgierda Grotta poddane szczegółowemu opisowi. Autor ograniczył się w swojej książce do działania IBSN i KNBZW oraz do scharakteryzowania ich prac. One to bowiem, jak słusznie zauważa, odgrywały główną rolę w badaniu kwestii mniejszości narodowych. Obydwie te instytucje osadzone zostały w książce Olgierda Grotta w szerszej problematyce, 
ing the issue of national minorities. Both of these institutions were embedded in the book by Olgierd Grott in the wider issues which was the ethnic policy of the country associated with the adoption of time-varying policy plans. The author devoted the first chapter of his treatise for those issues, showing in a synthetic way the situational context functioning of the main subject of his inquiry - IBSN and KNBZW. Yet we must remember that the policy was not uniform on over a relatively short period of the Second Republic, as far as initially they sought to create, through the so-called state assimilation, such a situation in which Slavic minorities would accept the Polish state. Later acknowledging the failure of these efforts, they assumed that the owner of the State should be considered not "political nation", but the "ethnic nation" or Poles. Therefore, they began efforts to multiply the Polish population in the Borderlands giving multifaceted care over the Poles living there and also trying to assimilate ethnic groups of non-crystallised national consciousness, as Lemkos, Boykos, Hutsuls or Poleszuks.

The second chapter concerns the structure of IBSN activity. All the agenda of the Institute were reconstructed and discussed in detail there. The author used for this purpose both archival materials preserved to this day after the war and full resource scientific production of the Institute, its periodical "Sprawy Narodowościowe" and works by researches cooperating with IBSN. Resource materials of the second type is a relatively complete set. Spread to jaką była polityka narodowościowa państwa powiązana z przyjęciem zmiennych w czasie zamierzeń politycznych, którym to zagadnieniom Autor poświęcił pierwszy rozdział swojej rozprawy, ukazując w sposób syntetyczny kontekst sytuacyjny funkcjonowania głównego przedmiotu swych dociekań, czyli IBSN i KNBZW. Pamiętać trzeba przecież, że polityka ta nie była jednorodna w ciągu stosunkowo przecież krótkiego okresu II Rzeczypospolitej, o ile początkowo dążono do wytworzenia na drodze tzw. asymilacji państwowej sytuacji, w której mniejszości słowiańskie akceptowałyby państwo polskie, o tyle później uznając fiasko tych starań, przyjęto, że za właściciela państwa należy uznać nie „naród polityczny”, ale „naród etniczny”, czyli Polaków. W związku z tym rozpoczęto starania w kierunku pomnażania żywiołu polskiego na Kresach, roztaczając wieloaspektową opiekę nad tamtejszymi Polakami czy też usiłując asymilować grupy etniczne o niewykrystalizowanej świadomości narodowej, jak Łemkowie, Bojkowie, Huculi czy Poleszucy.

Rozdział drugi dotyczy struktury działalności IBSN. Zostały tam zrekonstruowane oraz w sposób szczegółowy omówione wszystkie agendy Instytutu. Autor wykorzystał do tego celu zarówno zachowane do dzisiaj po zniszczeniach wojennych materiały archiwalne, jak i pełny zasób produkcji naukowej Instytutu, a więc jego pismo pt. „Sprawy Narodowościowe” oraz druki zwarte autorstwa współpracujących z IBSN badaczy. Zasób materiałów drugiego typu stanowi zbiór stosunkowo kompletny. Rozproszony po wielu Bibliotekach naukowych uniknął zniszczeń wojennych, 
many scientific libraries avoided the war devastation, which the materials in the Institute in Warsaw were exposed to. Quite a lot of work is devoted to the structures of the Institute, which did not directly relate to the Eastern issues. As author emphasizes, however, this was done deliberately in order to present the institution which had in the field of its interest other ethnic issues, which, however, were not so well investigated in relation to issues related to the Eastern borderlands. In the second part of this chapter Olgierd Grott also gives comprehensive information on the research scope of the Institute on issues related to the problems of the eastern borderlands of Poland. The author presents there the activities and the problems addressed by the Ukrainian Commission, the Belarusian-Lithuanian Commission and the Jewish Commission and thus the body for these minorities, which had significant impact in the eastern borderlands. He also discusses the Commission for the position of the Poles in the former USSR and the sections dealing with the general situation of minority issues in the international field and nationalist issues in neighboring countries. It is good that the author highlighted this last issue, since it represents a reference point for issues of particular minorities in II Republic. minority issues in other countries played a similar, though not identical, role, with special emphasis on neighboring countries. Equally valuable is undoubtedly a detailed presentation of functioning the Population-Migration Department, which from the very beginning na co były narażone materiały znajdujące się w samym Instytucie w Warszawie. Stosunkowo dużo miejsca zostało tu poświęcone strukturom Instytutu, które w bezpośredni sposób nie odnosily się do kwestii wschodnich. Jak podkreśla jednak Autor, zostało to zrobione $\mathrm{z}$ premedytacją, $\mathrm{w}$ celu zaprezentowania placówki mającej w polu swego zainteresowania także inne kwestie narodowościowe, które jednak wyraźnie niedomagały $\mathrm{w}$ stosunku do zagadnień związanych z Kresami Wschodnimi. Natomiast $\mathrm{w}$ drugiej części tego rozdziału Olgierd Grott podaje również wyczerpujące informacje dotyczące zakresu badawczego Instytutu w kwestiach związanych z problematyką kresów wschodnich Rzeczypospolitej. Przedstawiona została tam działalność i problemy podejmowane przez Komisję Ukraińską, Komisję Litewsko-Białoruską oraz Komisję Żydowską, a więc ciała dotyczące tych mniejszości, które na kresach wschodnich wyciskały swoje piętno w sposób bardzo wyraźny. Osobno zostały też omówione Komisja do spraw położenia Polaków w ówczesnym ZSRS oraz sekcje zajmujące się ogólną sytuacją problematyki mniejszościowej na terenie międzynarodowym i zagadnieniami narodowościowymi w państwach ościennych. Dobrze się stało, że Autor uwypuklił tę ostatnią kwestię, gdyż stanowi ona pewien punkt odniesienia dla zagadnień poszczególnych mniejszości w II Rzeczypospolitej. Podobną przecież, choć nie identyczną rolę odgrywały kwestie mniejszościowe w innych krajach, ze szczególnym uwzględnieniem państw ościennych. Równie wartościowe jest bez wątpienia szczegółowe zaprezentowanie 
was appointed to carry out a series of ambitious and long-term projects, such as economic influences of seasonal emigration from Polish territories to Latvia, analysis of emigration from Poland to Palestine, the demographic nature of Poland including issues of real and natural population movement in the years 1921-1931, the issues of internal migrations, population growth, urbanization and the state of its dynamics in Poland, etc. It showed the development prospects of the course of IBSN actions. An unquestionable advantage of this dissertation is a detailed treatment of the above departments of IBSN, because they present the whole character of this institution and its role within the fields of both internal and foreign policies of the state.

The third chapter of the reviewed work concerns the Commission for Scientific Research of Eastern Territories. The internal layout of this chapter, although based on a different grid of points, in general corresponds to the second chapter, where the author also first discussed the structure of the Commission. Subsequently, the departments of KNBZW were presented. Their task was to study issues relating to the natural, economic and demographic conditions of Eastern Territories. Units of this type, which the author presented meticulously, grouped around the more specific issues and problems occurring in different from each other areas. So, in this place separate departments for mountain lands, north-eastern, south-eastern, Polesie and Volyn and Chełm Land were distinguished and described in this place. funkcji Wydziału Populacyjno-Migracyjnego, któremu od samego początku wyznaczono do realizacji wiele ambitnych i długoterminowych projektów, jak np. wpływy gospodarcze sezonowej emigracji z terenów Polski na Łotwę, analiza wychodźstwa z Polski do Palestyny, charakter demograficzny Polski obejmujący zagadnienia rzeczywistego i naturalnego ruchu ludności w latach 1921-1931, kwestie wędrówek wewnętrznych, przyrost zaludnienia, stan urbanizacji i jej dynamika w Polsce itp. Podobnie przybliżenie Seminarium Narodowościowego, które miało kształtować młode kadry badaczy zagadnień narodowościowych. Świadczyło ono o perspektywach rozwojowych kierunku działań IBSN. Bezsprzeczną zaletą rozprawy jest szczegółowe potraktowanie powyższych agentur IBSN, gdyż unaoczniają one w pełnym zakresie oblicze tej instytucji oraz jej rolę w obrębie kierunków zarówno wewnętrznej, jak i zagranicznej polityki państwa.

Rozdział trzeci recenzowanej pracy dotyczy Komisji Naukowych Badań Ziem Wschodnich. Wewnętrzny układ tego rozdziału, choć oparty na innej siatce punktów, w ogólnym zarysie odpowiada rozdziałowi drugiemu. Tu również w pierwszej kolejności omówiona została struktura Komisji. W dalszej kolejności przedstawione zostały komórki KNBZW, których zadaniem było badanie spraw dotyczących warunków naturalnych, ekonomicznych i demograficznych Ziem Wschodnich. Jednostki tego typu, co skrupulatnie przedstawił autor, grupowały się wokół bardziej szczegółowych zagadnień i problemów występujących na odmien- 
The structures of these regions were different and therefore the creation of special units to study them was fully justified. What is important, the author did not take the raised issues altogether. In his book, he distinguished every region, whom separate committees created in the structures of KNBZW were devoted. It is good it happened that way because we are talking about the great heterogeneity in terms of the possibility of development of individual regions and their potential colonization and the heterogeneous nature of the local minorities living there.

In the next part of his dissertation, the author discusses the activities of the Faculty Population-Migration Department. This unit researched a very important matter in the grid of demands regarding the ethnic transformations on the Polish lands. It was expected that emigration of representatives of national minorities from these lands would release a place for Polish colonists and therefore this issue was closely related to Polonization. In addition, O. Grott presented the scientific achievements of reporting meetings summarizing the activities of various committees, which worked in the area of Polesie and the Central and Eastern Carpathians. Because of their specificity, the areas became primarily the subject of the research interests of the presented institutions. On the other nych od siebie obszarach. Wyróżniono więc i opisano w tym miejscu osobne komórki dla ziem górskich, północno-wschodnich, południowo-wschodnich, Polesia i Wołynia oraz Ziemi Chełmskiej. Struktury tych regionów były rozmaite, a więc stworzenie specjalnych jednostek do ich badania było w pełni uzasadnione. Autor, co ważne, nie potraktował poruszanych zagadnień w sposób zbiorczy. Wyróżnił w układzie książki poszczególne regiony, którym zostały poświęcone powstałe w strukturze KNBZW odrębne komisje. Dobrze, że tak się stało, albowiem mieliśmy przecież do czynienia $\mathrm{z}$ wielką niejednorodnością w kwestii możliwości zagospodarowania poszczególnych regionów oraz ich ewentualnej kolonizacji oraz heterogenicznym charakterem zamieszkujących tam mniejszości lokalnych.

W dalszej części swej rozprawy autor omawia działalność Wydziału Populacyjno-Migracyjnego. Placówka ta zajmowała się badaniem bardzo istotnej sprawy w siatce postulatów dotyczących przekształceń etnicznych na ziemiach polskich. Spodziewano się bowiem, że emigracja z tych ziem przedstawicieli mniejszości narodowych zwolni miejsce dla kolonistów polskich, a więc kwestia ta wiązała się ściśle z polonizacją. Ponadto przedstawiony został dorobek naukowy zjazdów sprawozdawczych podsumowujących działalność poszczególnych komisji, a więc tych, które działały na obszarze Polesia i Karpat środkowych i wschodnich. Ze względu na swą specyfikę te właśnie obszary stały się w pierwszym rzędzie przedmiotem zainteresowań badawczych omawianych instytucji. Ostatni rozdział rozprawy 
hand, the last chapter of this work concerns minor gentry or duniwassals, so a group of people living in many borderland villages, who due to their unique location and awareness of distinctiveness in relation to the surrounding peasant community, in the first place, according to the ratings of state authorities, was to repolonized. It was believed that a properly conducted action in relation to the gentry quickly and significantly would affect the desired (by the Polish institutions) change in nationality relations of the eastern regions of Poland. In this regard, it was stated that:

work among the minor gentry $[\ldots]$ has the revindication-national character, because $80-90 \%$ of so-called minor nobility in Eastern Galicia was considered until recently as the Russian or Ukrainian element, and this is because most of them use the Rus language in the home and are Greek Catholics (p. 193).

In the course of reading of the reviewed book you can notice a certain conspicuous disproportion when it comes to the presented issues. It is fair to say that it is rather not a result of negligence or superficial treatment of certain issues by the author, or his personal preferences. In large part this is due simply to the fact that the specific issues attracted unequally attention of these institutions and individuals associated with them, therefore, there is a certain eccentricity with regard to the subject matter to be analyzed. In large part this was the result of constant financial dotyczy natomiast szlachty zagrodowej zwanej też zaściankową czy chodaczkową, a więc grupy ludności zamieszkującej licznie kresową wieś, która ze względu na swoje specyficzne położenie i świadomość odrębności w stosunku do otaczającej ją społeczności włościańskiej, w pierwszym rzędzie, według ocen władz państwowych, nadawała się do spolonizowania. Uważano, że właściwie prowadzona akcja w stosunku do szlachty zagrodowej szybko i wydatnie wpłynie na pożądaną przez czynniki polskie zmianę stosunków narodowościowych ziem wschodnich RP. W związku z tym stwierdzano, że:

praca wśród szlachty zagrodowej [...] nosi charakter rewindykacyjno-narodowy, gdyż 80-90\% tzw. szlachty zagrodowej w Małopolsce Wschodniej uważane było do niedawna za element ruski wzgl. ukraiński, a to z tego powodu, że większość używa w domu języka ruskiego i jest obrządku greckokatolickiego (s. 193).

Rzuca się w oczy w trakcie lektury recenzowanej książki pewna dysproporcja jeżeli chodzi o poruszaną problematykę. Trzeba jednak uczciwie powiedzieć, że nie stanowi to raczej wyniku jakiegoś niedopatrzenia czy powierzchownego potraktowania niektórych zagadnień przez autora, ewentualnie jego osobistych preferencji. $\mathrm{W}$ dużej mierze wynika to po prostu $\mathrm{z}$ faktu, że poszczególne kwestie cieszyły się niejednakowym zainteresowaniem omawianych instytucji i osób z nimi związanych, w związku z tym mamy do czynienia z pewną nierównomiernością jeżeli chodzi o poddawaną analizie tematykę. $\mathrm{W}$ dużej mierze było to wynikiem nieustannych 
problems, which both institutions struggled with. The

institute compared its own finances to the amounts received from the state by a similar body functioning in Germany at the same time. The amounts of all the subsidies from different ministries for IBSN (Ministry of the Interior 3000 zł, Press Department of the Ministry of Foreign Affairs 500 PLN, Department of International Systems of the Ministry of Foreign Affairs 500 PLN, Eastern Department the Ministry of Foreign Affairs 1500 PLN) were together 5500 PLN per month, while the Internationales Institut für Minderheitsforschung with its outbuildings generated monthly $5850 \mathrm{DM}$, which when converted for the purposes of this study the average exchange rate of the year 1929 (1 Deutschmark = 2.11 PLN) gave the amount of 12,343.5 PLN (p. 226).

They studied in this context, what was most needed at the very moment, what concerned the most urgent issues, the most urgent and up-to-date.

Needless to say, the author managed to capture the most important aspects of the analyzed institutions in the eastern borderlands. Based on archival sources as well as literature he described very clearly the tasks they performed and the role filled in the whole of the policy pursued by the government camp after 1926. The undeniable advantage of the work is that clearly and explicitly it links the activities of IBSN and KNBZW with the process of ideological changes in the Pilsudskiite camp regarding national minorities. $\mathrm{He}$ indicates at the same time as under the influence of this reorientation the role and tasks of the mentioned institutions kłopotów finansowych, z którymi borykały się obydwie instytucje.

instytut porównywał własne finanse do sum otrzymywanych od państwa przez podobną organizację funkcjonującą w Niemczech w tym samym czasie. Kwoty wszystkich subsydiów od poszczególnych ministerstw dla IBSN (MSW 3000 zł, Wydział Prasowy MSZ 500 zł, Wydział Ustrojów Międzynarodowych MSZ 500 zł, Wydział Wschodni MSZ 1500 zł) wynosiły razem 5500 zł miesięcznie, podczas gdy Internationales Institut für Minderheitsforschung ze swoimi przybudówkami generował miesięcznie sumę 5850 marek, co po przeliczeniu dla celów niniejszego opracowania po średnim kursie rocznym z $1929 \mathrm{r}$. (1 marka niemiecka = 2,11 złotego) dawało kwotę 12343,5 zł (s. 226).

Badano w związku z tym to, co było najbardziej potrzebne w danej chwili, dotyczyło kwestii najpilniejszych, najbardziej palących i aktualnych.

Trzeba powiedzieć, że Autorowi udało się uchwycić najistotniejsze aspekty działalności analizowanych przez siebie instytucji na kresach wschodnich - opierając się na źródłach archiwalnych, jak też literaturze przedmiotu, określił on bardzo wyraźnie zadania przez nie realizowane i rolę, jaką odgrywały w całokształcie polityki realizowanej przez obóz rządzący po $1926 \mathrm{r}$. Niewątpliwym walorem pracy jest to, że jasno i wyraźnie wiąże on działalność IBSN i KNBZW z procesem przemian ideowych w obozie piłsudczykowskim odnośnie do stosunku do mniejszości narodowych. Wskazuje jednocześnie, jak pod wpływem tej reorientacji zmieniała się rola i zadania wzmiankowanych instytucji oraz na ile one same wpływały poprzez prowadzone przez siebie badania na zmianę polityki rządzących w tej sferze. Trzeba 
changed and how they influenced by their conducted research on the change in policy of the government in this area. One must remember that we are dealing with two main stages of minority policy pursued by the Sanacja camp. In the first one they wanted to consolidate the state accepting as minimum the state assimilation of its citizens. In the second stage, as a result of the experience of growing nationalism of ethnic minorities inhabiting the Second Republic, first and foremost, of course, Ukrainian nationalism, which branches carried even terrorist activities, they took actions in the spirit of nationalism. The expression of which were the efforts of repolonization of Eastern Galicia, demolition of Orthodox sacred objects on the Chelm region and also the dismissal of the governor of Volyn region Henryk Józewski who led liberal nationality policy in the territory. The watershed time here was the death of Marshal Pilsudski who was the supporter of the state assimilation as well as finding the Promethean idea obsolete, which proved to be an inadequate method for carrying out the decomposition of the USSR. The author skillfully linked functioning in both IBSN and KNBZW actions just with these ideological changes. He did not limit to the reconstruction of the structures of the institutions, whose history he analyzed. His work is a very important contribution to the deepening of knowledge of national issues of the Second Republic, solving of which provide evidence for both the regime and the whole political philosophy. Launching gradual measures bowiem pamiętać, że mamy do czynienia $\mathrm{z}$ dwoma głównymi etapami polityki mniejszościowej realizowanej przez obóz sanacyjny. W pierwszym chciano skonsolidować państwo, zadowalając się asymilacją państwową swych obywateli, w drugim zaś, na skutek doświadczeń z narastającym nacjonalizmem mniejszości narodowych zamieszkujących tereny II Rzeczypospolitej, przede wszystkim oczywiście nacjonalizmem ukraińskim, którego ekspozytury prowadziły przecież nawet działalność terrorystyczną, podjęto działania $\mathrm{w}$ duchu nacjonalistycznym, wyrazem czego były dążenia do repolonizacji Małopolski Wschodniej, burzenie prawosławnych obiektów sakralnych na Chełmszczyźnie czy też zdymisjonowanie wojewody wołyńskiego Henryka Józewskiego prowadzącego na podległym mu terenie liberalną politykę narodowościową. Cezurą czasową była tu śmierć marszałka Piłsudskiego będącego zwolennikiem asymilacji państwowej, a także stwierdzenie pewnej dezaktualizacji idei prometejskiej, która okazała się niewystarczającą metodą dla przeprowadzenia dekompozycji ZSRS. Autor umiejętnie powiązał funkcjonujące zarówno w IBSN, jak i KNBZW działania z tymi właśnie przemianami ideowymi, nie poprzestał na rekonstrukcji struktury samych tylko instytucji, których dzieje wziął na warsztat naukowy. Praca jego stanowi bardzo istotny przyczynek do pogłębienia znajomości spraw narodowościowych II Rzeczypospolitej, których metody rozwiązywania świadczą zarówno o jej ustroju, jak i całej filozofii politycznej za tym stojącej. Uruchomienie stopniowych działań nakierowanych na mniejszości na- 
aimed at national minorities in the Eastern Borderlands, where the instrument was to be IBSN and KNBZW, was interrupted by the aggression of the Third Reich and the USSR. Hence it did not develop fully and, moreover, these institutions did not produce results consistent with the expectations of their initiators. Nevertheless, they are an important part of the internal history of the Second Republic. As the author concludes:

Despite the uncomfortable conditions associated with a deficiency of funds, it should be noted as positive the dedication and the will of making up for financial shortfalls with creativity of the Commission staff. You can also safely say that despite having modest as to the pursued objectives means, the research was being continued. It was work intended to give rise to a maximum polonization of Eastern Borderlands, and thereby inhibiting the expansion of the nationalistic elements striving for the emancipation which were negatively assessed by the political camp ruling then Poland. On its results, they planned to develop a real activity on several parallel areas. First, they wanted to strengthen and enlarge with all available means the Polish element living in the Eastern Borderland. Secondly, they planned to expand the Borderlands in economic terms, and thirdly, it was the objective to reach the Poles living in native Polish frontiers with the information that the eastern territories are an integral and a very important element of the Second Republic, and therefore they should be given the greatest help. [...] One thing is for sure. If the continuity of the duration of the Polish state had not been interrupted tragically, the case of Eastern Borderlands would have been given concrete solutions for which the Second Republic did not have simply enough time. The right path of activities at the com- rodowe na Kresach Wschodnich, których narzędziem miał być IBSN oraz KNBZW, zostało przerwane przez agresję III Rzeszy i ZSRS, siłą rzeczy więc nie rozwinęło się w pełni, a tym bardziej działania tych instytucji nie przyniosły efektów zgodnych z oczekiwaniami ich inicjatorów. Niemniej jednak stanowią one istotną część wewnętrznej historii II Rzeczypospolitej. Jak konkluduje autor:

Pomimo niekomfortowych warunków związanych $\mathrm{z}$ niedoborami funduszy, jako pozytyw należy wskazać poświęcenie oraz wolę nadrabiania braków finansowych pomysłowością personelu Komisji. Można również śmiało powiedzieć, że mimo dysponowania skromnymi jak na realizowane cele środkami, praca badawcza mająca dać podstawy do maksymalnego spolszczenia Kresów Wschodnich, a tym samym zahamowania ekspansji dążących do emancypacji elementów narodowościowych negatywnie tym samym ocenianych przez rzadzący ówcześnie Polską obóz polityczny, szła do przodu. Na jej rezultatach planowano rozwinąć realną działalność na kilku równoległych płaszczyznach. Po pierwsze, chciano wzmocnić i powiększyć wszelkimi dostępnymi środkami żyjący na Kresach Wschodnich element polski, po drugie, planowano rozwinąć Kresy pod względem gospodarczym, a po trzecie, stawiano sobie za cel dotarcie do Polaków zamieszkujących rdzennie polskie rubieże $\mathrm{z}$ informacją, iż Kresy Wschodnie stanowią nieodłączny oraz bardzo ważny element RP, a w związku z tym należy im wyjść naprzeciw i okazać jak największą pomoc. [...] Jedno jest pewne. Gdyby w sposób tragiczny nie została przerwana ciągłość trwania państwa polskiego, to kwestia Kresów Wschodnich musiałaby doczekać się konkretnych rozwiązań, na które II RP nie starczyło po prostu czasu. Azymut działań na dzień rozpoczęcia II wojny światowej w kwestii Kresów Wschodnich był już starannie wytyczony. Kierunek ten, jak wiemy, nie został rozwinięty. Naturalny bieg spraw przerwała 
mencement of World War II on the Eastern Borderlands was neatly laid out. This direction, as we know, was not developed. The natural course of events was interrupted by the Nazi aggression. Burning in September 1939 of the building occupied by IBSN, which was the first research institute, which took a comprehensive approach to the issue of the eastern lands, can be symbolic. Fire caused by a German bomb destroyed forever the achievements of the Institute. The question of the Eastern Borderlands came in the last, while tragic chapter of their history (pp. 229-230).

The Work was also equipped with the iconographic material constituting a valuable addition enriching the whole. Moreover, it has the Appendix, which contains important source materials such as a report from the General Assembly of IBSN (1928-1939), a list of the real members of IBSN from the years 1927-1939, Bibliographic description of agrarian-economic regions monographs of south-eastern Poland regions (Volyn, Lvov, Tarnopol and Stanislawow), a list of titles of each series of IBSN publications and the list of maps developed by the Cartographic Section of IBSN. agresja hitlerowska. Jako symboliczny można poczytać fakt spłonięcia we wrześniu $1939 \mathrm{r}$. gmachu zajmowanego przez IBSN będącego pierwszym instytutem naukowo-badawczym, który podjął się kompleksowego ujęcia kwestii ziem wschodnich. Pożar wywołany niemiecką bombą zniszczył bezpowrotnie cały dorobek Instytutu. Kwestia Kresów Wschodnich weszła w ostatni, a jednocześnie tragiczny rozdział swojej historii (s. 229-230).

Praca zaopatrzona została również w materiał ikonograficzny stanowiący wartościowy dodatek wzbogacający całość, ponadto zawiera także Aneks, w którym zamieszczono istotne materiały źródłowe, jak np. sprawozdanie z Walnego Zgromadzenia IBSN (1928-1939), listę członków rzeczywistych IBSN z lat 1927-1939, Opis bibliograficzny monografii agrarno-ekonomicznych województw południowo-wschodnich RP (wołyńskiego, lwowskiego, tarnopolskiego i stanisławowskiego) czy Listę tytułów poszczególnych serii wydawnictw IBSN czy Spis map opracowanych przez Pracownię Kartograficzną IBSN.

\section{Olgierd Grott, Instytut Badań Spraw Narodowościowych i Komisja Naukowych Badań Ziem Wschodnich w planowaniu polityki II Rzeczypospolitej na Kresach Wschodnich, Księgarnia Akademicka, Kraków 2013, pp. 303.}

